\title{
Building Emotional Resilience: Japanese Women's Religious and Spiritual Coping Strategies in the Time of COVID-19
}

\author{
Paola Cavaliere (10
}

Citation: Cavaliere, Paola. 2021 Building Emotional Resilience: Japanese Women's Religious and Spiritual Coping Strategies in the Time of COVID-19. Religions 12: 723. https://doi.org/10.3390/rel12090723

Academic Editor: Enzo Pace

Received: 2 August 2021

Accepted: 31 August 2021

Published: 3 September 2021

Publisher's Note: MDPI stays neutral with regard to jurisdictional claims in published maps and institutional affiliations.

Copyright: (C) 2021 by the author Licensee MDPI, Basel, Switzerland. This article is an open access article distributed under the terms and conditions of the Creative Commons Attribution (CC BY) license (https:// creativecommons.org/licenses/by/ $4.0 /$ )
Graduate School of Human Sciences, Osaka University, Osaka 565-0871, Japan; pcavaliere@hus.osaka-u.ac.jp

\begin{abstract}
This paper explores the moderating effect of religious and spiritual coping mechanisms on the COVID-19 pandemic-induced emotional distress among a group of Japanese women practising temple meditation and yoga. A growing body of literature identifies religion and spirituality as sources of coping mechanisms for emotional distress during the pandemic, in that they enable individuals to find ways to improve subjective well-being and quality of life. The study uses a descriptive phenomenological approach, drawing upon narratives collected between September 2020 and June 2021 from thirty-two respondents composed of a mix of religious-affiliated and self-identified non-religious women practising temple meditation and yoga. Findings indicate that more women, including religious affiliates, have favoured spiritual coping mechanisms in the forms of meditation and body-mind practices to build emotional resilience. This reflects a quest for greater subjective well-being to compensate for the increased burden of emotional care during the pandemic. Overall, while organised religions have come to appropriate more holistic forms of spirituality to respond to demands of emotional care, body-mind spiritual practices have become more appealing for younger religious and non-religious Japanese women alike, in that they downplay gender-conforming ideas of the care economy with its emphasis on dedication and dependency.
\end{abstract}

Keywords: COVID-19 stress; Japan; emotional care; gender; religion; spirituality

\section{Introduction}

In direct comparison, the COVID-19-related number of deaths and infected cases in Japan has been far lower than figures seen in other developed countries (WHO 2021). However, the safety measures and repeated states of emergency ${ }^{1}$ have had escalating socio-economic consequences named by the Japanese media as the korona-ka, the "coronavirus disaster." In a country already under economic and demographic crisis, the pandemic has exposed structural, socio-economic, and individual vulnerabilities. Since mid-2020, female suicides in Japan have surged by $22 \%$, mostly affecting women in the 16-to-40-year-old age cohort, particularly among high school students and housewives (Cabinet Office of Japan 2021a, p. 21; Nomura et al. 2021). Suicide rates among Japanese men, on the other hand, have continued the downward tendency of the past decade (Cabinet Office of Japan 2021a, p. 21). Men's unaltered trend is thought to be related to improved lifestyles due to COVID-19-induced safety measures, with them spending more time at home, teleworking, less stressed by not having to commute to work, as well as enjoying a healthier diet of home-cooked food and fewer after-work drinking parties (Cabinet Office of Japan 2021a, p. 19). Overall, data reveal that the socio-economic and psychological impact of the COVID-19 crisis is not gender-neutral. As of March 2021, the number of consultations for domestic violence had almost doubled as compared to the previous year (Cabinet Office of Japan 2021b), while the alarming phenomenon of young carers-junior and high school students who look after younger siblings or provide nursing care for elderly family members (MUFJ 2021) — seems to partly explain the doubled suicide rate among school-age girls over the past year (Cabinet Office of Japan 2021a, p. 22). Although not all domestic work is done by women, household management and 
care tasks such as providing for family well-being and performing emotional labour as tending family relationships are core responsibilities of women and girls in contemporary Japan (Cabinet Office of Japan 2021a, p. 29). The following excerpt from the narrative of a study participant, a 37-year-old member of the new religion Shinnyoen, ${ }^{2}$ offers ground for situating the topic of this study:

During the first state of emergency last year, my husband started working from home, and my two elementary school children switched to remote learning. My mother-in-law's elderly day-care centre closed, so she moved in with us, and I have cared for her since then. The social welfare office said it would not be possible for them to visit two places, so my father-in-law [who lived separately] also moved in. My apparel company did not renew my part-time contract because of the reduced demand during closure. We needed my salary, but I felt I had to do my best to support my family and care for everyone's mental health ('kokoro no kizu hiyashite ageyo $\bar{o}^{\prime}$ ). After a year, we are in the third state of emergency. I keep preparing meals paying attention to everyone's nutrition needs, I make my children study, I bathe, feed and care for my in-laws, and I clean our crowded house. I stopped going to the [Shinnyoen-sponsored] early morning cleaning activities, I am too busy. I used to attend the [Shinnyoen] meetings once a week; now I am joining the online meetings for members once a month. Honestly, even finding time for one monthly meeting has become difficult. Every time I hear about the pandemic on TV and in newspapers, I burst into tears. I was driven by the idea that my [Shinnyoen] lineage parent used to say: that I could do anything as long as I had a family and trust in others. But I have started questioning what family is and how my religion has been helping me cope with my everyday problems. I needed something else. (Noriko, 37, Shinnyoen member)

The above account reveals that, in the case of the pandemic, gendered vulnerability does not derive from sole socio-demographic factors such as household composition or income: it exposes intersections with social institutions, cultural patterns, structural inequalities, employement status, and personal life choices that create precarious social conditions and have a strong impact on women's well-being. Moreover, Noriko's religious belonging and belief do not seem to have provided her with emotional resilience. Yet, religiosity and spirituality are known sources of coping strategies for emotional distress in challenging times (Gard et al. 2014; Bryce Yaden 2019; Lucchetti et al. 2019; de Rezende-Pinto et al. 2019; Nita 2019). While the mechanisms underlying the association between spirituality, religiosity, and emotional health outcomes are not yet completely understood (Ano and Vasconcelles 2005; Ivtzan and Papantoniou 2014; Guendelman et al. 2017; Büssing 2019), spirituality and religiosity have already been positively correlated with individuals' capacity to adapt and cope with the difficulties and stressors of the pandemic (Lucchetti et al. 2020; Ferrell et al. 2020; Del Castillo et al. 2020; Pirutinsky et al. 2020; Edara et al. 2021). As such, spirituality and religiosity are identified as sources of resilience in that they enable individuals to enact strategies improving subjective well-being and quality of life.

Drawing upon such a growing body of literature, the purpose of this study is to intersect the analysis with the gender factor, exploring what religious or spiritual coping mechanisms a group of Japanese women have enacted to care for their emotional wellbeing during the pandemic. The purpose is to explore their experiences, delving into the moderating role of religious belief and spirituality in their search for emotional resistance, documenting coping mechanisms that are used to minimise their emotional distress.

The following section offers details of respondents and addresses methodological considerations. Next, the paper contextualises the circumstances of women in Japan since early 2020, and identifies the pressing issues they are facing as they go through the COVID19 pandemic. The study also outlines institutional responses that religious organisations have enacted, and provides information on the latest development of the spiritual care movement in Japan. The remainder of the paper will situate respondents' narratives against 
this background and discuss the significance of religious and spiritual sources of resilience for respondents searching for coping mechanisms that can assist them with the difficulties and emotional pressures of the current situation.

\section{Methodology}

\subsection{Study Design}

This qualitative study uses descriptive phenomenological analysis to conceptualise the extent to which religious affiliates and non-religious respondents source from or side-line components of religion (committed belief, rituals, and religious community) favouring spiritual alternatives as a strategy of emotional and spiritual support. It draws upon qualitative data collected between September 2020 and June 2021 from a pool of thirtytwo respondents taking part in yoga classes and temple meditation. Twenty-two semistructured interviews of women aged between 25 and 60 constituted raw data for narrative analysis. Among the thirty-two respondents available, ten declined to be interviewed individually due to lacking time, but accepted to be included in the records of informal conversations held before and after their yoga or meditation sessions.

\subsection{Setting and Participants}

All respondents were women who lived in the northwest of Osaka Prefecture. A few prospective participants were initially recruited through the yoga instructor. Snowballing sampling then helped identify other potential subjects. For inclusion in the study, respondents had to be active in unpaid care and domestic work and had to be new to the body-mind practices when they first started during the pandemic. Marital status, with or without children, and professional status were also assessed in the inclusion criteria so that the sample is consistent with the socio-demographic data of the average population identified in the "Study Group Report on Impacts and Challenges for Women during the coronavirus pandemic" issued by the Cabinet Office of Japan (2021a). In the sample, seventeen women attended the yoga classes held at a local community centre by a certified yoga instructor; fifteen women practised yoga and zazen meditation at the Kanzanji Buddhist temple of the Rinzai Zen school in Minō city, Osaka Prefecture. ${ }^{3}$ In April 2021, the yoga instructor initiated the "tera-yoga" (temple yoga) sessions, with more classes offered at the Kanzanji Buddhist temple as well as at other local temples in the area. ${ }^{4}$ The modality of yoga and meditation sessions alternated between online Zoom sessions and in-person, depending on the pandemic-related states of emergency. Frequently, regulars of the local community centre joined sessions at the Kanzanji Buddhist temple, where tera-yoga was offered. Interviews were held online over Zoom, although several informal conversations were also possible during in-person sessions, which were integrated into the qualitative data.

Twenty-two respondents self-identified as members of a religious organisation or followers of a Buddhist religious tradition: eight respondents were affiliates of new religious movements (five members of Shinnyoen and three members of Tenriky $\bar{o}^{5}$ ); four respondents were Catholic; six were parishioners of the Kanzanji Rinzai Zen Buddhist temple where meditation and yoga classes were held; and four were parishioners of a local Buddhist Pure Land temple. Ten respondents self-identified as non-religious. Four men in their 40s also regularly attended the meditation and yoga sessions at Kanzanji temple. All participants self-identified as middle-class, sixteen living in an owned apartment, five in a rented apartment, and eleven in a single house. Eighteen women were married, ten were single, two were widowers, and two divorced. Twelve women were full-time housewives, nineteen women were engaged in paid employment (six full-time employees and thirteen part-timers or on fixed term contract basis), and one self-employed. Two full-time respondents were professional nurses; one woman worked in the financial sector; two worked as medical clinic administrative staff; and one worked as a care manager in a private elderly care facility. Five part-timers were retail salespersons; three worked at customer services in financial and real estate companies; two were employed at the city hall; two were hospital 
nurses; and one worked in the funeral service. All women in paid employment were also engaged in care and domestic work. Nineteen respondents were college-educated; nine held a bachelor degree, and four had a high school diploma.

\subsection{Data Collection}

Interviews were accomplished by the author and were digitally audio-recorded. These were conducted as semi-structured with both fixed and open questions. The following topic areas were covered during the interviews: (1) Socio-demographic data: age, profession, marital status, and household composition; education; and religious affiliation or not having a religion; (2) Description of the experience of the pandemic and sources of anxiety and stress; (3) Religious and spiritual beliefs: religious attendance and religious private activities; and the role of religion and/or spirituality as coping mechanisms and sources of self-care; and (4) Perceived benefits of practising yoga and/or meditation: emotional experiences related to spiritual practices of yoga and meditation; social capital (trust, sense of belonging, and connectedness with other yoga or meditation participants); impact on healing, emotional, and mental well-being, as well as coping and resilience. At the beginning of the interview, information was obtained about socio-demographic data, then, with the open-ended question such as 'Could you please tell me about your experience of the pandemic?' they were asked to describe their experience from the beginning and how it impacted their daily life. To obtain detailed accounts, questions such as 'When did you first start feeling uneasy or anxious regarding your situation?', 'What were the major causes of stress and anxiety?' 'How did you identify a need to communicate your uneasiness and find a way to cope with that?' were asked. In the following, questions such as 'How do you feel your religious belief and membership helped you in the coping process?' and 'What made you try yoga/meditation $i$ 'What do you think of the yoga/meditation experiences so far?, 'How do you think it has helped to cope with stress induced by the pandemic?' were also asked.

Participants were interviewed once for an average of one hour. Interviews were later transcribed and analysed using inductive content analysis with the use of the software NVivo. Japanese to English translation of interview data was performed by the author. Observation data in the form of descriptive notes were collected during in-person and Zoom sessions. Descriptive notes included: the content of conversations held before and after the sessions; information regarding interactions between participants and the yoga instructor, the temple priest, and his wife during sessions; interactions among participants and the content of their conversations; and questions asked during the sessions. The study was reviewed and approved by the Ethics Committee of the Graduate School of Human Sciences at Osaka University, and followed the ethical standards of the sponsoring Japan Society for the Promotion of Science (JSPS). Participation in the study was informed and voluntary; consent was obtained from all participants. All names in this paper have been altered to maintain respondents' anonymity. The study is part of a five-year project (2020-2025) on gender, religion, and disaster resilience sponsored by the Japan Society for the Promotion of Science.

\subsection{Data Analysis}

For the purpose of this research, religious coping is defined as "the use of religious beliefs or behaviours to facilitate problem-solving to prevent or alleviate the negative emotional consequences of stressful life circumstances" (Koenig et al. 1998, p. 513). On the other hand, spiritual coping indicates holistic body-mind practices that involve " ... a lived experience in relationship with our own bodies, with others, and with nature" (King 2009 , p. 4). In this study, two forms of body-mind spiritual techniques were considered: meditation and yoga. While there is no scholarly agreement in what distinguishes religion and spirituality, this study differentiates body-mind spiritual practices from the three dimensions of committed belief, ritual, and religious community that characterise religion, also implying 'a contemplative turn' towards subjectivity (Taylor 1991). 
This work adopted Colaizzi's (1978) seven-step analysis method for descriptive phenomenological approach to trace women's anecdotal evidence of religious or spiritual coping mechanisms during the pandemic, through which findings were systematised to reflect their own lived experiences: [1] Familiarization; [2] Identifying significant statements; [3] Formulating meanings; [4] Clustering themes; [5] Developing an exhaustive description; [6] Producing the fundamental structure; and [7] Seeking verification of the fundamental structure. Narratives were organised through the software NVivo from groups of meaning units into clustered statements leading to themes that will be discussed in the Results section. The final step of Colaizzi's method was particularly important, as it required the researcher to return the clustered statements and identified thematic areas to all participants for validation as to whether they capture their experience. In doing so, the researcher attempted to address potential bias in regard to subjective assessment of significant statements and identification of thematic areas.

\section{Background: Gender, Care, and Religion during the Pandemic}

\subsection{The Gender-Regressive Impact of the Care Economy during the Pandemic}

When the COVID-19 global pandemic struck in early 2020, Japan ranked 121st out of 153 countries on the 2020 Global Gender Gap Index (World Economic Forum 2020), the lowest among all advanced economies. The negative effect of COVID-19 on Japanese women has already been attributed to two factors: the disproportionate impact of the pandemic on sectors that tend to employ more women in non-regular jobs, such as welfare and health care services, tourism, hospitality, and entertainment (Cabinet Office of Japan 2021a, pp. 8-10); and the increase in family caregiving responsibilities due to kindergarten and school closures, partners' teleworking, and reduced eldercare services that fall on women's shoulders (Cabinet Office of Japan 2021a, p. 19). The deterioration of daily life conditions and the changes in lifestyles during the COVID-19-induced 'new-normal' are well-documented causes of a negative impact on mental health (Yamamura and Tsustsui 2021; Shigemura et al. 2020; Lima et al. 2020; Rajkumar 2020). A year into the pandemic, increasing socio-economic insecurity has intensified Japanese women's precarious status in employment, heightened unpaid workload, and undermined the living conditions of women across lower and middle social classes, a situation often exacerbated by their responsibility for caring for families. The current domestic arrangements find their roots in the "housewifisation process" (Ochiai 2013, p. 536) in the decades since the end of World War II, with a model of family characterised by a gender division of labour with men serving as breadwinners and women as housewives. The long-ruling conservative Liberal Democratic Party, with its interventionist style, has consistently promoted a family oriented social construct, embedding traditional views and moralities around family and gender roles. Such familist ideology implies that the family is the central social unit, where members should support each other so that they do not become burdensome to the state. Nowadays, ideologies and policies around womanhood, motherhood, and family persist, fuelling and reinforcing structural constructs around women's roles as mothers and wives in their caring and nurturing roles within the contemporary neoliberal family construct (Cavaliere 2021b). Scholars have already documented how Japanese mothers with children are particularly affected in case of a disaster, with altered family composition-usually from nuclear into extended households - which impacts domestic responsibilities, care work, productive labour, and community roles (Yamane 2013; Nishihara et al. 2018). They have also drawn attention to women as a potentially highly vulnerable population for their role as caregivers, particularly as heads of low-income households (Enarson 1998; Enarson et al. 2007). Traumatic effects of the COVID-19 pandemic have shown higher risk factors in females developing PTSD than their male counterparts (Xiong et al. 2020; Thibaut and van Wijngaarden-Cremers 2021), which many times manifest as depressive and anxiety symptoms. Noriko's narrative quoted in the introduction synthesises the qualitative impact of the pandemic on her everyday life, exposing the psychological impact on her mental well-being caused by structural and systemic inequalities associated with 
unequal employment conditions and dominant ideologies of family, womanhood, and motherhood, prescribing the tasks and duties of the unpaid "care economy" (Power 2020; Moreira da Silva 2019).

Findings published on April 28th, 2021 by the Gender Equality Bureau on the impact of the pandemic on women (Cabinet Office of Japan 2021a) show that promoting policies to facilitate women's participation in the paid economy have further cemented social expectations toward women in their traditional, gender-based roles. In addition to the direct impacts of the pandemic, the safety measures have exacerbated pre-existing inequalities structured upon the unaltered familist social construct. The rising suicide figures among women since the beginning of the pandemic have revealed the tip of the hidden iceberg made of gendered inequalities and contradictory demands, along with chronic, scant attention to Japanese women's actual needs. One crucial factor is that the recurrent states of emergency and the continued implementation of safety measures tend to consolidate a habit of unpaid extra-care provided by women in their implicit role of family carers to compensate for the pandemic-induced shortage of such care outside of the family. As Noriko's narrative quoted in the introduction suggests, the (re-)emphasis on the family as the shock-absorber during the pandemic - both compensating and finding solutions to reduced caring services as institutions and the paid care economy go through unprecedented challenges - is having a regressive effect on gender equality that makes women more vulnerable. While progress toward gender equality in Japan had been uneven even before the pandemic, the changing lifestyles of the COVID-19-induced 'new normal' regime seem to have furthered a gender-regressive context in which women are demanded to compensate for instability and uncertainty at any time.

\section{2. "Kokoro No Kea" during the Pandemic: Institutional Responses}

The onset of the pandemic has had a highly disruptive impact on the activities of churches, temples, shrines, and religious communities around the world. While such a growing alienation from religious places and events might as well enhance secularisation, scholarship has shown that the current pandemic has also intensified the need for spiritual coping mechanisms and increased people's religiosity (Pew Forum 2021; Bentzen 2020). In Japan, as elsewhere globally, asynchronous consumption of and largely reduced participation in interactive rituals of traditional religious culture might have accelerated trends associated with vanishing collective rituals and privatisation of religion. However, many prominent temples and shrines around Japan have continued to perform both old and new rituals to quell the coronavirus pandemic. For example, Sukunahikona shrine, a Shintō shrine in central Osaka that hosts the eponymous Japanese god of medicine, has attracted a large number of visitors (both online and in-person) seeking the popular omamori (amulets) that can help ward off COVID-19 and protect the carrier from the disease. ${ }^{6}$ Seeking divine aid in moments of distress is not unusual, and the Japanese have often shown a tendency towards pragmatic functionalism that make them "turn to gods in the times of troubles" (Reader 1991, pp. 1-21) and search for worldly benefits in their consumption of religious commodities (Reader and Tanabe 1998). The numerous ema (votive tablets) at Sukunahikona shrine with handwritten messages pleading for the swift end of the COVID-19 crisis are a clear sign of such intentions.

While these actions account for collective rituals and individual practices that require some embodiment, they should not be confused with religious beliefs. Drawing upon phenomenological elements to evaluate the emotional mechanisms of rituals (performed in a group) and practices (performed individually), recent research has generated a number of insights, especially in terms of health and well-being - in addition to other social, emotional, and cognitive dynamics - that both rituals and practices generate, which do not necessarily require a commitment to belief (Bryce Yaden 2019; Newberg 2019). A growing body of literature focuses on the role that religion plays during the pandemic, focusing on how beliefs, virtual communities, and social capital offer means to minimise social isolation and stress (Lucchetti et al. 2020; Boguszewski et al. 2020; Shechter et al. 2020; Arslan and Yildrim 
2021; Prazeres et al. 2021). In Japan, where the large majority of people describe themselves as $m u s h \bar{u} k y \bar{o}$, non-religious, the resilient capacity of religious institutions to enable social and emotional dynamics to overcome the pandemic-induced adverse situations affecting people's well-being has not diminished (Cavaliere 2021a). With temples, shrines, and churches in Japan dramatically downsizing or cancelling religious-related collective events, ceremonies, and rituals under the pandemic-induced distancing measures, individuals and institutions have adjusted and created new religious-cultural repertoires, symbolic meanings, and habits to cope with the COVID-19-driven sense of risk and uncertainty. The normative phenomenological experience of the Japanese-who engage in religious-cultural practices without necessarily adhering or belonging to a religious institution-seems to be resistant to a contingent process of fading popular religious-cultural occurrences from most public discourse as a result of the COVID-19 pandemic. As it happens, most churches, temples and shrines have responded to both usual and new demands of people looking for spiritual relief and religious commodities that would help them cope with heightened stress, distress, and anxiety caused by the pandemic.

Against this backdrop, a porous movement of seekers of supirichuaru kea (spiritual care)-also referred to as kokoro no kea (care of mind) by the media and health and religious professionals-has developed, composed of individuals who do not source only from conventional forms of collective rituals and popular religious-cultural activities for their emotional relief. Studies have shown that spiritual practices for self-care such as meditation, relaxation, and mind-body disciplines have been positively correlated with increased selfresilience during the pandemic (Lucchetti et al. 2020; Bartos et al. 2021; Sahni et al. 2021) in that individuals develop necessary resources-such as psychological and emotional resources-to self-regulate their behaviour and successfully adapt to stressful circumstances (Koenig 2008; Hart and Koenig 2020). Findings have already revealed the effectiveness of such self-resilience among the Japanese during the COVID-19 pandemic (Kubo et al. 2021; Sugawara et al. 2020). Temple meditation and related forms of mindfulness practicesalong with yoga and other body-mind disciplines-have become increasingly popular (Kato and Shaw 2020; Sado 2021) and publicly supported by the Japanese Ministry of Health, Labor, and Welfare, which appeals to such body-mind practices to cope with the COVID-19-induced stress and to boost well-being during the pandemic. ${ }^{7}$

In the Japanese context, spirituality is often discussed in relation to the subjective turn developed alongside the growth of conspicuous consumer culture of the Japanese society since the 1970s (Shimazono 2011; Horie 2021). While being used as an alternative to the wary category of shūkyō (religion) and organised religions since the Aum affair in 1995 (Horie 2009; Arimoto 2011; Cavaliere 2019a, pp. 99-102), certain components of the supirichuariti (spirituality) movement, such as the body-mind practices and meditation, have slowly been nuanced and absorbed into the supirichuaru kea and kokoro no kea phenomenon of the post-March 2011 triple disaster in Tohoku and Fukushima. The traumatic effect of the 2011 disaster prompted a vast demand for spiritual and emotional care to help cope with and adapt to such a traumatic individual and collective experience. The response came with the development of a non-religious spiritual and emotional care performed by religious and lay actors alike (Inaba 2018; McLaughlin 2013). In order to institutionalise such a form of spiritual care, in 2012 Tohoku University established the Department of Practical Religious Studies with the purpose of offering the new Spiritual Care Worker Education Program preparing lay and religious professionals in supirichuaru kea and kokoro no kea applicable to clinical settings by training them in the psychology of religion, psychotherapy, mental health care, and grief care. ${ }^{8}$ As such, supirichuaru kea and kokoro no kea have become widely accepted practices performed by both lay professionals and rinshō shūkyōshi, certified religious spiritual care workers. Several universities and medical organisations around Japan now offer the Spiritual Care Worker Education Program to provide professional training to spiritual care practitioners who operate under the supervision of the Society for the Inter-faith Chaplaincy in Japan, also complying with the directives of the Japanese Society for Spiritual Care and the Japanese Society of Certi- 
fied Clinical Psychologists (Taniyama 2017). The trainees include religious professionals, doctors, nurses, and social workers.

Building on such development, many religious actors in Japan have started offering spiritual and emotional care to cope with the COVID-19 effect. The government's limited response to pandemic-driven emotional and psychological stress has led religious professionals of Shintō shrines, Buddhist temples, and Buddhist-related new religions to expand their 'active listening volunteering' (keichō borantia), a core component of the supirichuaru $k e a$ approach. Among the trained practitioners is the chief priest of the Kanzanji Rinzai Zen Buddhist temple in Osaka, a certified spiritual care worker who has been offering training and advice on emotional care to the nurses in charge of COVID-19 patients receiving home care. ${ }^{9}$ While religious professional spiritual care is still a niche sector, as it requires practitioners to be officially certified as rinshō shūkyōshi, over the past year, more and more religious affiliates, including women, have started training at their organisations to offer forms of spiritual care.

\section{Building Emotional Resilience: Women's Narratives}

\subsection{Temple Meditation as a Coping Strategy}

The Kanzanji temple chief priest's wife (known as jitei in Japanese) and many regular women parishioners are not new to such forms of spiritual care. Some of them had already been offering kokoro no kea in the form of keicho borantia to residents in the local community before the advent of the pandemic. Historically, Buddhism in Japan has been associated with funerals and death, and therefore has rarely played a part in addressing or engaging with people's emotional distress or sense of precarity during life. The spiritual care movement discussed above, however, has lately informed many Buddhist institutions to actively engage in the field of everyday spiritual care contributing to the emotional resilience of local residents.

Since June 2020, Kanzanji temple's women's group (josei no tsudoi), typically restricted to regular women practitioners affiliated to the Hanazono joseibu no tsudoi (Women's Group of Hanazono) ${ }^{10}$ has opened to occasional temple-goers looking for zazen meditation and shakyo (sutra copying) experiences of the traditional Rinzai Zen Buddhism. The tsudoi used to be a weekly three-hour Buddhist training where women chanted a sutra, discussed a passage from the writings of a Rinzai Zen patriarch, sat in meditation, copied some parts of the sutra, and then had tea prepared by the jitei. During teatime, the temple chief priest's wife usually offered informal advice to her parishioners, drawing upon Buddhist precepts and moral teachings, also sourcing from the religious-based counselling and spiritual care of her husband's training. Although the jitei is not a certified rinshō shūkyōshi, she participated actively in her husband's Spiritual Care Worker Education Program and studied with him during his course preparation. In September 2020, more than fifteen new, non-regular women in their late 40s and 50s had joined the sessions the jitei holds twice a week, most of them over Zoom. In there, she guides participants in chanting and meditation while also interacting with them during the transition from one activity to the other. Although the content and format of the tsudoi used to be quite formal and rigid, it has adjusted to both the online modality and the diversity of the new women participants, most of them not particularly fond of Rinzai Zen Buddhism per se. In online sessions, participants spend some time in the beginning to greet and chat, then regular parishioners chant a sutra while the non-regular participants are "encouraged to listen quietly so that they can feel the sutra resounding in their mind (kokoro)" explains the jitei. After some meditation time, she guides a shakyō session, during which she adds some explanation of the sutra with real-life examples to clarify its applicability. While shakyo used to be part of religious training for Buddhist monks and nuns, it has become a popular means of meditation for occasional lay temple-goers. Participants of the Kanzanji temple sessions have become dynamic agents of the session where they interact with each other and with the jitei, who always offers hands-on advice and counselling on how to manage the stress and difficulties during the pandemic. At the end of the shakyō, everyone is invited to have 
some tea and share their thoughts or chat about their daily lives. Kyoko, a 46-year-old participant, says that

[attending the tsudoi] is really refreshing because every time I can hear from others and share my feelings. During meditation, I repeatedly receive the intensity of the moment. It's a special feeling, and it makes me feel better.

Kyoko was a full-time employee at an insurance company, married to a medical healthcare specialist working at a university hospital. Given her husband's work at the COVID-19 frontline, in the middle of the second state of emergency Kyoko's employer recommended she refrained from going to work for fear that she might bring the infection into the workplace. Although she acknowledged the discrimination, she did not want to confront the prejudice and felt she had no choice to avoid adverse treatment from her employer and co-workers.

I had to 'voluntarily' quit, I was really frustrated. I had to support my husband and help him relax at home, although he was unsupportive about my situation. It was a terrible time, I was just about to give up. (akirameyo to shite ita)

After reading posts on an online platform on the beneficial outcomes of meditation, she decided to try out the activities offered by the Kanzanji temple. In her description of the tsudoi, Kyoko uses the verb "receive" (ukeru) to describe the feeling she gets from the session and adds that the meetings create a particular atmosphere that infuses her. She describes this as a yasashii kimochi, an expression that conveys the sense of comfort, warmth, and caretaking. She admits that she does not know much about Rinzai Zen and does not understand most of the sutra they recite or copy, but the meditation, the chanting, and the talking with others have a healing power that holds a positive effect. This way, women who may not know each other and might not know Buddhist doctrine may still find support and feel emotional relief that helps them cope with their sense of isolation and insecurity.

Rie is a 48-year old married woman who lives in a house not far from Kanzanji temple. Her husband is a company employee, and her two male children had both moved out from home in 2019. The younger, however, had returned home in September 2020 after his employer closed down his business activity due to the impact of COVID-19. Since May 2020, her husband's company had shifted to teleworking for three days a week. Her father-in-law, a relatively healthy man in his 80 s, also lives with them. Rie comments that she feels pressure now, more than when her children were school age, as caring for adults during the pandemic requires "to be always positive and supportive so that they don't get negative thoughts or feelings. Because they depend on me (watashi ni tayotteiru)." Rie regularly attends the zazen meditation sessions that the temple has been offering to the general public since September 2020, and occasionally joins the weekly tera-yoga classes held in there "so that I can take time off from domestic duties and take care of myself for some time." She says that she enjoys tera-yoga as she can do some exercise in a familiar environment, and the fact that it is held in the temple makes it an acceptable practice for her family too. She is not a danka member, a parishioner of the temple, so she was initially reluctant to join the activities. It was a neighbour who convinced her to join and insisted that she attended the online meditation sessions too.

I enjoy our meditation sessions, and I have befriended some of the participants. I have spent my life cultivating relationships in a passive way, with relatives, with my husband's colleagues, with mothers of my children's classmates, or with the neighbour because they live next door. Now I have made friends with people who share my interest in doing something for ourselves. I feel I have finally grown up (laugh)! [yatto otona ni natta ki ga shimasu]

Due to the burden and the stress of the pandemic, she had been suffering from insomnia and almost collapsed during the summer of 2020. Rie says that the meditation sessions and the talks with the priest and his wife have taught her how to devote attention to herself during the day, and have helped her feel better. The temple priest is often joined 
by his wife during the after-meditation talks, and together they chat about the importance of simple, everyday things such as cooking, cleaning, or chatting as forms of self-care. Rie says that:

[Housework] has become a sort of spiritual practice. With this pandemic and everyone depending on me at home, I feel I can't breathe. So the priest and his wife started giving us suggestions to review things that might have become stressful, such as spending time in a crowded home. The jitei told us to think about things in a new way, teach our mind to stay focused on what we are doing, when folding clothes, or preparing food, for example. It helps clean up my mind. [kokoro o katazukeru]

These pieces of domestic wisdom and many of the "everyday meditation activities" mentioned by the jitei and her husband are, for the most, related to traditionally gendered activities where women are expected to cook, clean, and organise. In Japan, the latest prepandemic survey shows that, on weekdays, women spent $4 \mathrm{~h} 23 \mathrm{~min}$ on housework, seven times that of their husbands (Cabinet Office of Japan 2021a, p. 4). The abrupt change in family composition and daily routines brought about by the pandemic has almost doubled women's housework along with a strong emotional component attached to such domestic work (Cabinet Office of Japan 2021a, pp. 21-23). Back in February 2021, Rie and the other nine participants of the meditation sessions spent quite some time discussing the derogatory remarks on women made by the then president of the Tokyo Organizing Committee of the Olympic and Paralympic Games, Mr Mori Yoshiro. ${ }^{11}$ Some of them read the Twitter messages and posted replies on the hashtags \#wakimaenai onna tachi (women who do not know how to conduct themselves) and \#DontBeSilent. On one occasion, they had a heated discussion about what wakimaeteiru onna (women who know their place) meant to them. Most of them argued that, while domestic duties and a life of household chores might be exhausting, especially during the pandemic, they still felt some reward in their work and a role to play in building and supporting family solidarities. However, Mr Mori's remarks had brought up questions about respect and purpose in life, and above all, the very meaning of their interpersonal dependency. Everyone agreed that 'knowing your place' was a source of vulnerability as it assumed that women prioritise the needs of others, thus establishing unbalanced dependency relations. While the gender complementarity still appealed to them, as it gave them a role of responsibility, the difficulties and complexities of providing emotional care and support to everyone that the wakimaeteiru onna implied during the pandemic had become a burden they felt unrewarding and almost overwhelming.

As it happens, rather than challenging the expected gendered roles and the emotional burden of their tasks, the jitei offered women participants practical advice to improve their condition from the within, with ways to adjust their everyday routines and translate activities into meaningful actions for self-assertion. In her words, there is a strong emphasis that women who are burdened with housework and caring for spouses, relatives, or children during the pandemic deserve time to themselves more than before. The jitei and her husband's ideas resonate with concepts of mindfulness, with its focus on helping individuals realise that they have a right to their well-being and happiness. In fact, during his rinsho shūkyōshi training, the temple priest practised mindfulness regularly and studied the seminar material with his wife. As such, some understandings of mindfulness must play a part in the way they interact with women, although they make sure to tailor their suggestions specifically to them by including gendered nuances. While their understanding of women's caring role and flexibility frames upon the gender complementarity complying with the idea of "women who know their place," there is an emphasis on assisting women in the difficult task of constructing healthy relationships and developing more autonomous, self-respectful forms of selfhood. Building on meditation and mindfulness, the jitei and her husband guide participants to deconstruct some ideas of women's pliancy, flexibility, and care for the others so that they come to include individual well-being and self-care in their daily life. Although they rarely use the term "mindfulness" in their talks, the jitei and her 
husband's interactions with women clearly resound that method and its accompanying expected positive results.

Many respondents stated that practising temple meditation had brought a variety of emotional improvements in that they have started paying more attention to their everyday life, translating housework activities to spiritual moments. Some of them expressed a sense of inner peace: "I have a very good feeling, especially when I stay focused long enough to forget what I have to do next. I feel relaxed" (Yumi, 46). Others comment on the improved ability to withstand problems, including caring and financial worries. The process goes through repositioning themselves in a frame where they had almost disappeared:

Now I see myself and what I do. It makes me feel better. I know everything wouldn't be okay, but it makes me stronger to stand problems. Because I see how much I am doing for my family, and I understand when I need a break. (Mari, 51)

\subsection{Building Emotional Resilience through Yoga}

The 37-year-old Noriko mentioned in the introduction is a regular of the yoga classes held at the local community centre. In December 2020, she started occasionally joining the tera-yoga classes at Kanzanji and decided to participate in the tsudoi a few times. As a member of Shinnyoen, she thought that the zazen meditation was no different from the sesshin sessions she attends at Shinnyoen:

[ ... ] only [at Shinnyoen] we interact with a reinōsha (a trained medium, spiritual guide $^{12}$ who offers us individualised advice, while here it is an open conversation where everyone shares their concerns, and the jitei offers her guidance.

After sitting in a few tsudoi sessions, she dropped them, but continued to join the yoga classes at the community centre and occasionally the tera-yoga at the temple. From her perspective, "transforming my everyday habits into elevated ones that can be interpreted as spiritual actions... that's difficult. I have the same problem (iwakan o kanjiru) when my lineage parent (suji oya) or the reinōsha tell me so." She also feels a generational gap: "they [women attending the tsudoi] are full-time housewives, they somehow understand the hurdles of caring for the family while also supporting the family income, but have no experience of that." When asked to articulate a little further her view of herself as a Shinnyoen member, she comments that she finds her organisation has helped her deal with moments of crisis in life and her marriage, and she is grateful for the level of en (human relationships with family and society) that she has been able to establish through their guidance. However, over the past year, she has developed a need to "be me, not what I ought to be." Noriko has started feeling a sense of estrangement from her religious organisation, with the way the group related the causes of her individual problems to karmic connections and to ancestors: "sometimes I feel I am unable to connect it with my real life."

Mayu is a 31-year old mother of a baby girl who was born in February 2021. She is a university-educated Catholic who used to work as a registered nurse before getting married in 2018. Her husband is an anesthesiologist at the local city hospital, which is not far from their house located in a relatively affluent area of the city. When Mayu realised she was pregnant, she started worrying about her baby and began spending hours looking up the prenatal effects of COVID-19 on internet. The lack of evidence-based research concerned her. She called her obstetrician, who cautioned that due to the unknowns, she should consider limiting her exposure to the virus as much as possible. Under the COVID-19 safety measures, her numerous regular antenatal health checks were reduced to three. Mayu cut her social contacts too, to the point that she started avoiding her husband at home for fear that he would expose her to the virus.

I felt such a heavy responsibility for my child's health to the point that everything else, including myself, disappeared. I spent days searching for information online on the impact of COVID-19 on a foetus. I stayed inside my bedroom, avoiding my husband as much as possible. I am a Catholic, I prayed, but I could not get any 
relief. And I didn't want to meet anyone from the church, they would insist that I shared my feeling with them so that they could help. I was getting depressed and anxious.

In September 2020, she found information about the yoga classes being held online. She made contact with the instructor and joined the trial Zoom session.

The yoga teacher told us that we should welcome problems and bad moments as occasions for us to wake up, make us react and change for the better. It's a difficult process, but it helps seeing things from a different perspective. I have been practising yoga since then, almost with no interruption before and after giving birth. I am a nurse, I know I was depressed. That helped me get back in control of my life.

While studies have shown that women experience mild to moderate anxiety and/or depression during pregnancy (Dayan et al. 2006; Rubertsson et al. 2014), the COVID19 seems to have had serious consequences on individuals' subjective well-being and psychological functions in general (Khoury et al. 2021; Y1ldirım and Arslan 2020). What makes Mayu's case interesting is the resilient capacity to bounce back, side-lining her Christian faith, leading her to seek a spiritual coping mechanism for herself. In Mayu's words, by practising yoga, she has "learned how to see myself breathing and find my balance. I no longer need to conceal my distress [fuan o kakusu]. I can actually take care of my mental health [jibun no kokoro o mamoru yō ni natta]." The process went alongside her disillusion with the Christian religious organisation, an institution she knew well but, in the moment of need, was perceived as a source of potential distress due to its collective and normative components.

I left my job as a nurse because my colleagues and friends at the church told me I should not work after getting married. I got pregnant during the pandemic, bad timing. But practising yoga helped me understand the importance of establishing priorities in life: it should be less about what other people, or our church believe your priority should be. The real risk of infection during pregnancy, that is a serious reason, one that would really justify quitting a job.

Similar to Mayu, other religious affiliates, all of them aged between 25 and 40, mentioned the discomfort (iwakan) they sensed as members of their religious organisation during the pandemic, in that they felt being measured as women. The pandemic and its impact on family and social dynamics have shaken their beliefs and trust in values around womanhood promoted by their religious institutions. In May 2020, when most religious organisations had to dramatically reduce their activities, many had already started connecting with like-minded people over anonymous online platforms to share their concerns or search for models of healthy lifestyles and routines beyond their religious organisation. In their search for mechanisms to "care for themselves," traditional religions with their focus on acceptance and dedication seemed more a hindrance than a source of coping and resilience. Respondents of this study have not rejected their faith, but they feel at odds with ideals of feminine care, an ethic of self-sacrifice, domesticity, and spiritual and moral responsibility for the family. Findings show that they prioritise body and emotion-focused practices that help them gain control of themselves over the net of dependencies they live in.

\section{Results}

With the closing of religious institutions and potential disruptions to religious members' normal practices, this study was particularly interested in exploring participants' views of how they were coping during this unique time and the role that spiritual practices could play to handle the impact on their well-being created by this pandemic. Participants were asked to reflect on and share their thoughts on the open questions related to the role of religion and spirituality as coping mechanisms and sources of self-care outlined in the methodological section. Six major thematic areas of findings were identified from 
the raw analysis of information they shared. Theme 1: 'Help wanted' was revealed in descriptions of acknowledging the need for help to cope with the stressful COVID-19-related situation; Theme 2: 'Making sense' included descriptions about ways that informants explored to make sense of their need for coping mechanisms during the pandemic; Theme 3: 'Recognising usefulness/uselessness' emerged from descriptions of how religious beliefs and spiritual practices could be used as coping strategies. This stage includes informants' descriptions of the extent belief or spirituality were perceived to provide a sense of self-care; Theme 4: 'Engaging in communication' covers the descriptions of the informants' capacity to express and share their distress and need for emotional care with others, including family members; Theme 5: 'Practice as coping strategy' emerged from informants' descriptions of the impact of the temple meditation and/or yoga activities on participants' everyday pandemic experience. Lastly, Theme 6: 'Emotionally charged' emerged from descriptions of emotional experiences related to spiritual practices of yoga and meditation.

The first two thematic areas (1: Help wanted and 2: Making sense) were interconnected and were discussed within and across questions, largely focusing on ways that participants were responding to the crisis. Women's responses were very similar across the sample, indicating the altered daily lifestyles, deterioration of the household environment and increased care and domestic work as the main sources of anxiety and stress. In search of ways to mitigate the detrimental effects on their lives of the new environment created by the COVID-19-and with disruptions to their normal religious practices in the case of religious members-responses to these qualitative questions indicated that many women identified forms of meditation and body-mind practices as appropriate coping mechanisms for their emotional well-being. Such a search of meditation and body-mind practices was triggered by and associated with a quest for greater subjective well-being to compensate for the increased burden of emotional care. As it happens, findings show that body-mind spiritual practices such as yoga and meditation were favoured and sought after by non-religious and religious adherents alike.

In contrast, two factors differentiated most strongly the responses in the remaining four thematic areas (3: Recognising usefulness/uselessness; 4: Engaging in communication; 5: Practice as coping strategy; 6: Emotionally charged): age and employment status of the respondent. The interrelation between seeking alternatives and resilient solutions to respondents' struggles with the age and employment status of respondents is evident in the narrations reported in the previous section, which offered insights into the reasons for diverging dynamics and responses that women enacted to alleviate the emotional distress of the pandemic-induced everyday reality. Full-time housewife women in the 45-65 age cohort were more inclined to accommodate the altered situation impacting on their emotional well-being without dramatically altering their commitment to domestic work and care. They were attracted by institutional activities of organised religion such as temple meditation and related practices led by the head of the temple and his wife that re-emphasised the importance of their role in the domesticity, which made them feel emotionally rewarded. Respondents of the tsudoi and temple meditation sessions reported that, through meditation and the other activities, they developed a feeling of connection to themselves they had never experienced before. Such an awareness influenced their understanding of everyday life, bringing closer attention to them as having equal importance as everyone else. A central point of commonalities among narratives of older respondents was a sense of emotional relief combined with the acceptance of a self in relation not defined and shaped upon others' expectations. Women stressed a capacity to acknowledge their needs and resources, which made them more capable of managing everyday problems and the emotional stress of the family with its dependency dynamics. Such capacity impacted the way they faced family demands by altering routines centred on prioritising others' well-being, which positively correlated with their emotional well-being. Overall, spiritual practices in the tsudoi and meditation sessions created opportunities for connection, served as sources of strength, and provided pathways for thriving during a time of emotional challenges. 
In comparison, younger women in the 25-45 age cohort, most of them employed either part-time or full time, represented the counter-narrative to the older women's accounts, mainly lamenting uneasiness toward prescriptive care roles within the family and dissatisfaction with institutionalised religion. Such an attitude seemed to interrelate with growing disenchantment with institutional religion's appeal to be wakimaeteiru onna, "women who know their place" and are committed to domestic work and care. As it happens, both religious and non-religious younger respondents were much less attracted by institutional practices and favoured body-mind activities that were not associated with organised religion. In this respect, three distinctive narratives emerged from accounts of younger religious affiliates. Firstly, a sense of disenchantment toward institutional religion, making them feel unattuned with its ethic of complete dedication in the form of altruism and self-sacrifice that it delivers. Secondly, an enjoyment in putting their body and mind at work by challenging themselves with new forms of spirituality as compared to praying or passively attending collective religious rituals. The reduced time spent in their religious organisations allowed them to explore alternatives: practising yoga gave them a stronger sense of confidence in their physical and emotional potentials, also helping them assess their limitations in their dependency relationships and their caring roles. Thirdly, it promoted a sense of inner strength in their self-determination for their well-being that helped enact resilient mechanisms and cope with the stressful situation. The process went through the acceptance of self as relational individuals, but not as much as a dependent one, and as subjects in need of coping strategies. All these aspects were interwoven and closely knitted together to create the composite structure of how building emotional resilience was experienced by them.

\section{Discussion: A Trend toward Spiritual Coping Mechanisms during the Pandemic}

Since the beginning of the COVID-19 pandemic, respondents of this study have made an effort to navigate the crisis, difficulties, emotional and physical stress, uncertainty, and urgency. While government policies have been promoting women's access to the labour market also as an expression of their capacity of self-responsibilisation and selfdetermination, meanings of womanhood and motherhood in the twenty-first century's Japanese neoliberal society have been kept essentially unchanged. In this context, the ideology of care emerges as burdening women, who seem to have to shoulder most of the socio-economic and emotional cost of the pandemic. In her analysis of women's condition in 2020 in the United Kingdom, sociologist Heejung Chung similarly found that women are "ensuring the emotional well-being of not only $(\ldots$ ) children but also parents and other family members. In other words, they are in charge of the mental load of worrying about the family" (Chung 2020). The qualitative data presented in this study align with the emotional impact of the pandemic described by Chung, which often relates to a sense of lower self-efficacy and inability to absorb the heightened care needs of their families. COVID19-related challenges and experiences have caused Noriko and the others to question the quality of their lives and their lack of well-being, also prompting a search for coping mechanisms against stress and emotional distress in order to gain some degree of subjective control. While situating themselves in the prescribed role of providers of emotional care, women have also become seekers of such care and support. In their search for coping strategies and mechanisms, they have engaged in body-mind practices that assist them in the novel and challenging task of caring for themselves in a time when relational care is most pressing. This study defines such practices as spiritual to differentiate them from the dimensions of committed belief, ritual, and religious community that characterise religion.

The shift to online worship might have enhanced a subjective turn bringing individuals to seek direct spiritual experiences bypassing the religious institution (Cavaliere 2021a, p. 17). Scholars of religion would view such estrangement from organised religion as a tangible aspect and measurement of secularisation and individualisation of religion. On the other hand, scholarship has already indicated a trend toward "lived religion" (McGuire 2008; Ammerman 2014) in which individuals transfer their sense and search of the sacred 
into ordinary everyday living. The case of women of the tsudoi and meditation sessions at Kanzanji temple is an example of such a trend of attaching a sacred nuance to everyday life experiences. Here, religious practices appropriate the use of spirituality as a domain intersecting and sometimes equating with religiosity while retaining a certain distinction from it by denoting the specific discovering, experiencing, and the living component of the spiritual experience. Such assimilation of body-mind spiritual practices into religious practices to cope with the pandemic-induced emotional distress is not unrelated to the long-term response to spiritual care demands developed in the aftermath of the March 2011 triple disaster. The ongoing need for trained spiritual care workers to provide post-disaster spiritual care and the spread of formal programs to equip religious and lay professionals with psychotherapy training and meditation practices applicable to clinical settings have created a climate of acceptance of spiritual care and self-care body-mind practices performed in a religious context and by religious professionals. While some forms of religion are still sometimes viewed with suspicion in Japan, and people are still surprised by seeing clergy operating with healthcare workers, an increasing number of religious professionals are being trained in a mix of keichō volunteering, psychotherapy, and mindfulness practices. In so doing, religious professionals are taking spiritual healing practices and creatively combining them with their own traditions and cultural norms to provide support in ways that are more attuned with a majority of individuals who self-identify as non-religious.

The main finding of this study lies in the documentation of the growing women's preference for self-care and the resilience value that body-mind spiritual practices offer over the dimensions of committed belief, ritual, and religious community that characterise religion. As narratives in this study tell us, the urgency to find coping mechanisms to make women resilient in response to stressful circumstances of the pandemic has resulted in two main trends. Firstly, while the literature suggests that religion offers cognitive and emotional tools to deal with uncertainty and adversity, this study shows that institutional belonging might play a role for older full-time housewife women who still adjust with ideas of gender complementarity and family caring duties promoted by traditional religions. For these latter ones, housework and care constitute their professional status, and they feel rewarded by practices and beliefs that honour such forms of labour. As such, a form of mindfulness during housework taught by a temple priest proves beneficial to older women who are not bound by paid work and search for self-fulfilment in their domestic role. Working women who also perform unpaid domestic care work are less inclined to second that, as concentrating and enjoying the present moment while doing household chores or caring for others comes down to a religious and cultural belief in accepting a woman's role or place in the family system. As such, meditation and mindfulness practices offered by a religious institution are not suited for younger working women as they do not deal directly with the difficulties of providing paid and unpaid work. For younger respondents of this study, religion was neither congenial to their search for coping mechanisms nor a significant emotional tool they could rely on for their well-being. Their experiential preference for non-institutional mind-body practices over institutionalised rituals and temple practices was crucial and contributed to their coping

Secondly, while there is a tendency to view the spirituality movement in Japan as a gendered consumption phenomenon in that most providers and users of spiritual services and goods are women (Arimoto 2011, pp. 148-67; Isomura 2007), such scholarly definition largely overwrites the emic meaning of women's experience. Findings of this study show that a better understanding of women's increased preference for body-mind spiritual practices and estrangement from traditional religion would come from relating it with their challenging everyday living conditions during the pandemic, while also intersecting it with their age and their professional status. As scholars have pointed out, women's distancing from religion might happen for no more reason than they find institutionalised religion itself unsatisfactory or questionable (Woodhead 2008; Aune 2015; Komatsu 2017). According to Woodhead, many women are attracted to spirituality as it deals directly with the difficulties of their feminine condition and helps develop ways to care for women's stress and tensions 
in their everyday lives (Woodhead 2008, p. 191). This stance is not new to feminist scholars, who tie the origins of spirituality to the development of the feminism movement in the 1960s (Aune 2015). With feminism contributing to the way women have questioned gendered social expectations, spirituality developed as an alternative form to the patriarchal order of institutionalised religions and as a domain where women can express their shifting identities. As it happens, spirituality is sought for by those women, including religious affiliates, who juggle between the two sets of commitments and types of work of the mother and the working woman that the "neoliberal motherhood" (Cavaliere 2021b) entails. During the pandemic, the increase in the unpaid "dependency work of caring for those who are inevitably dependent" (Kittay 1999, p. IX) due to kindergarten and school closures, partners' teleworking, growing housework, and reduced eldercare services that fall on women's shoulders, might have increased a need to evade dependencies, without necessarily cutting them off. The concurrently self-assertive and relational component of spirituality, affirms Woodhead, poses that caring for others is conditional on one's wellbeing (Woodhead 2008, p. 191). As such, spirituality differs from traditional and organised religion in that it assists women in the difficult construction of more attuned alternatives to the traditional demands of self-sacrifice and limitless dedication. From a micro perspective, the pandemic-induced emancipation from institutional religion seems to have expanded a blending between what scholars distinguish as religious and spiritual, with more women, including religious affiliates, engaging in spiritual practices as means of coping and finding well-being for themselves and their families during the COVID-19 pandemic.

The socio-economic status of respondents-all of them self-reported middle-class women-should also not be underestimated as a key factor in women's solution-seeking behaviour. Recent surveys on the impacts of socio-economic factors on psychological and emotional health in the early phases of the COVID-19 pandemic in the general population in Japan show that low-income and precarious employment are negatively related to helpseeking behaviours, especially among younger women (Nagasu et al. 2021; Sugaya et al. 2021; Yamamoto et al. 2020), also affecting their mental health (Saito et al. 2021). This is identified as a category that is less inclined to seek emotional care and support (Ueda et al. 2020). Since the onset of the pandemic, some larger Japanese new religions have directed resources to non-profit organisations that provide support to low-income women: several women keichō borantia (active listening volunteers) of the Risshō kōseikai ${ }^{13}$ church in Osaka, for example, have been cooperating over the past year with the local branch of the Befrienders Osaka, a non-profit working in suicide prevention. The religious organisation also provides financial support for the non-profit's training courses, help services, and consultations via hotline and social media. The local churches of the Roman Catholic Church of Japan in Tokyo and Osaka have also responded by expanding their social capital, financial resources, and support services around domestic violence, psychological harassment, and child abuse. Since the beginning of the pandemic, the association has been offering consultations, shelter, and legal advice to women who become unemployed due to being laid off and those who are or might become victims of harassment or abuse, as well as those with suicidal thoughts.

Overall, findings suggest that spirituality, rather than religion, offers supportive resources to manage middle-class women's emotional stressors during the pandemic. Affiliates and non-religious alike engage in body-mind spiritual practices that have come to intersect and blend with what scholars would define as religious practices. Despite the digital shift in institutional religions, the pandemic has significantly decreased the demands on affiliates of in-person activities such as prayers, rituals, taking part in religious observances, volunteer activities, or church and temple gatherings. This might have given affiliates more autonomy to engage in diverse practices that can better respond to their needs to cope with stress, uncertainty, and isolation brought about by the pandemic. 


\section{Limitations}

Some limitations of this study must be discussed. First, a larger sample size would strengthen the present findings and identify more situational factors that lead women to elect spiritual practices. Including other forms of holistic body-mind practices would also inform us of the impact on emotional resilience that such different practices have. Secondly, the sample was composed of women who self-identified as middle-class. As this study has identified age and employment status as two key factors informing women's preference for spiritual practices, including a more varied employed women population would help further assess the effect of such socio-demographic components. Thirdly, although the final step in Colaizzi's data analysis method (returning the results to the participants for validation) might have helped limiting the author's potential bias in the subjective assessment and abstraction of raw interview data and observation material, this study uses definition of categories and the analysis of the information that were carried out by a single researcher. As such, further research and analysis conducted by investigators working independently could improve results' reproducibility and reliability. Finally, the results of this study offer a glimpse of the impact of the current pandemic on women and their coping mechanisms, also in relation to the latest developments in organised religion and the spiritual care movement. While the discussion anticipated some changes in religious values and practices, future research should consider the long-term implications and impact on religion as an organising and institutionalised entity of the assimilation of body-mind spiritual practices into religious practices.

\section{Conclusions}

The pandemic-induced closures, the structure of women's labour participationwhich is more likely to be temporary, flexible, and less remunerative-and the normative ideologies of motherhood prescribing caring roles have revealed the fragility of Japanese women's everyday lives. Government policies and dominant discourses in Japan still fuel and reinforce structural constructs around women's roles as mothers and wives in their caring and nurturing roles within the institution of the family. As such, women in Japan are expected to act as the main caregivers and absorb the emotional distress that family members experience during the pandemic. For some of them, such a heightened burden has played a crucial role in triggering their search for ways to care for themselves. Respondents of this study, a mix of religious affiliates and self-identified non-religious middle-class women, joined temple meditation, yoga, and other holistic well-being practices to seek emotional support and a focus on self-care. While it is not clear how spirituality and religiosity work as coping mechanisms, a functionalist view of them has long indicated that they help individuals deal with adversities, overcoming everyday difficulties, and building emotional resilience. Based on phenomenological analysis of respondents' narratives, the study explored the lived experiences of a pool of thirty-two Japanese women and studied how they enacted coping mechanisms challenging and, in some ways, reinforcing institutional constructs. Women described pathways leading them to approach spiritual practices, the reasons and ethical considerations related to prioritising spiritual over other religious-based coping mechanisms, and integrating strategies accorporating religious resources into their spiritual coping mechanisms.

This study shows that a gendered trend toward spirituality during the pandemic in Japan might be associated with two interconnected socio-cultural and socio-economic dynamics. Firstly, the normative phenomenological experience of the Japanese who engage in religious-cultural practices without necessarily adhering or belonging to a religious institution aligns with the contemporary idea of spirituality being integrated into a religious context to respond to demands of spiritual care. Such a process has come to overlap with an expansion of spiritual and emotional care and related self-care practices in the postMarch 2011 disaster in Japan, where an increased number of religious professionals have taken over the role of providers of spiritual care and self-care practices. These have come to be incorporated into traditional religious practices and settings and performed by 
religious professionals trained in counselling and psychotherapy techniques applicable in clinical settings, thus absorbing the means and needs of contemporary Japan's expanding spiritual care movement. Secondly, rather than a sign of furthered secularisation due to the reduced religious-related collective rituals, the pandemic-related spiritual shift holds a close link with the socio-economic status and age of respondents. Even before the pandemic, Japanese women had been pushed toward the mutually contradictory pressure to take active roles in the labour market in self-determined, self-fulfilling, and self-realising ways. Such a trend toward individualisation as an effect of the neoliberal discourses and policies has overlapped with unchanged values and views of family and the genderbased division of labour of post-World War II-Japan, where women are subjected to the urgent demand to fulfil their role as mothers in order to generate economic growth amid a trend of falling childbirth and a hyper-ageing society. Despite the attempts in structural adjustment, policies introduced in the past two decades have not had a demonstrable effect on improving women's living standards and work-life balance. Across lower and middle social classes, women are subject to such a complicated and exhausting reality of the neoliberal femininities that demand committed motherhood combined with self-realisation. In this context, traditional religions appeal to those women who are less burdened by the socio-economic impact of the pandemic: they still support traditional cultural values of the importance of women's relatedness and social connectedness rebranded in terms of gender complementary where motherhood and home-life comply with neoliberal values regarding femininity. As findings of this study have shown, the socio-economic impact on middle-class women in their 20s and 40s has made religious affiliates disenchanted with traditional ideas around family and motherhood supported by the gender complementary worldview of traditional religions and new religious movements. An emic perspective on spirituality during the pandemic reveals that body-mind spiritual practices have become more appealing as they tend to downplay gender-conforming ideas of the care economy and its emphasis on dedication and dependency.

In the light of such findings, this paper concludes that, in the Japanese context, the current global pandemic is expected to spark increased demand for spiritual comfort and emotional support beyond institutional religion that might as well be provided by religious professionals. Spirituality affirms the importance of caring for oneself and for self-affirmation, an emphasis that translates care into a form of construction of autonomous selves. This aspect is likely going to increasingly appeal to younger Japanese working women burdened by the emotional and socio-economic impact of the pandemic, including religious affiliates, who are looking for ways to disengage from their implicit gendered and dependency roles.

Funding: This research was funded by the Japan Society for the Promotion of Science, grant number 20K02135 (https:/ /kaken.nii.ac.jp/grant/KAKENHI-PROJECT-20K02135/).

Institutional Review Board Statement: The study was conducted according to the guidelines of the Japan Society for the Promotion of Science and approved by the Association for the Promotion of Research Integrity (Protocol code AP00000530951; date of approval: 10 November 2020).

Informed Consent Statement: Informed consent was obtained from all subjects involved in the study.

Data Availability Statement: The data presented in this study are available on request from the corresponding author. The data are not publicly available due to a pledge of confidentiality between the corresponding author and the respondents.

Conflicts of Interest: The author declares no conflict of interest. 


\section{Notes}

1 Four states of emergency have been declared in Osaka Prefecture so far: the first from 7 April to 25 May 2020; the second from 8 January to 21 March 2021; the third from 25 April to 20 June 2021; and the fourth from 2 August to 31 August 2021. See https: / / corona.go.jp/emergency / (accessed on 1 July 2021).

2 Shinnyoen (meaning "borderless garden of truth") is a new Buddhist religious movement founded in 1936. In 2020, the movement had 940,099 members, including 19,662 male and 84,072 female teachers of faith (Bunkachō 2020, p. 71). For a profile of the organization, see (Cavaliere 2019b).

3 https://www.minoh-kanzanji.com/ (accessed on 1 July 2021).

4 See https://www.vysyogi.org/ (accessed on 1 July 2021).

5 Tenrikyō is a Shintō-related new religious movement that bases its doctrine on the revelations her foundress, Nakayama Miki (1798-1887) had over the years between 1838 and 1887. In 2020, it counted 4,311,346 affiliates (Bunkachō 2020, p. 87). For an overview see (Cavaliere 2018).

6 See http://www.sinnosan.jp/ (accessed on 1 July 2021).

7 See https://kokoro.mhlw.go.jp/etc/coronavirus_info/column/ (accessed on 1 July 2021).

8 See https://www.sal.tohoku.ac.jp/en/research/specializations/lab/---id-28.html (accessed on 1 July 2021).

9 Information collected by the author.

10 Kanzanji temple belongs to the largest Rinzai Zen branch of Myoshinji in Kyoto, which directly supervises the Hanazono Buddhist Rinzai University and all the other educational facilities.

11 In a press conference on 3 February, 2021, Mr Mori, a former prime minister, responded to a question asking him to comment on the Olympic committee's plan to increase the number of women board members to more than $40 \%$ of the total. He commented that "on boards with a lot of women, the board meetings take so much time" but that "all the seven women currently in the executive board know how to conduct themselves" [wakimaete orarete imasu]. (https://www.asahi.com/articles/ASP2B64X0P2BUTIL001.html, accessed on 1 July 2021). The remarks sparked an outcry among international media and triggered a wave of online responses with such hashtags as \#wakimaenai onna tachi or \#DontBeSilent that eventually led to Mori's resignation on 11 February 2021. For an analysis of the sesshin and the role of reinōsha see (Cavaliere 2019b, pp. 146-49).

13 Based on the Lotus Sūtra (Hokekyō in Japanese) and inspired by Nichiren Buddhist tradition, Risshō kōseikai is a new religious movement founded in 1938 on the initiative of Niwano Nikkyō (1906-1999) and female co-founder Naganuma Myōkō (1889-1957). Risshō Kōseikai has 2,283,023 members (Bunkachō 2020, p. 79). For an overview, see (Cavaliere 2015, pp. 37-46).

\section{References}

Ammerman, Nancy T. 2014. Sacred Stories, Spiritual Tribes: Finding Religion in Everyday Life. Oxford: Oxford University Press.

Ano, Gene G., and Erin B. Vasconcelles. 2005. Religious coping and psychological adjustment to stress: A meta-analysis. Journal of Clinical Psychology 61: 461-80. [CrossRef] [PubMed]

Arimoto, Yumiko. 2011. Supirichuaru shijō no kenkyū: Dēta de yomu kyūkakudai māketto no shinjitsu (Research on the Spiritual Market: The Truth of the Rapidly Expanding Market Drawn upon Data). Tokyo: Tōkyō Keizai Shinpōsha.

Arslan, Gökmen, and Murat Yildrim. 2021. Meaning-Based Coping and Spirituality During the COVID-19 Pandemic: Mediating Effects on Subjective Well-Being. Frontier in Psychology 12: 646572. [CrossRef] [PubMed]

Aune, Kristin. 2015. Feminist spirituality as lived religion: How UK feminists forge religio-spiritual lives. Gender E Society 29: 122-45. [CrossRef]

Bartos, L. Javier, María J. Funes, Marc Ouellet, M. Pilar Posadas, and Chris Krägeloh. 2021. Developing Resilience During the COVID-19 Pandemic: Yoga and Mindfulness for the Well-Being of Student Musicians in Spain. Frontiers in Psychology 12: 642992. [CrossRef] [PubMed]

Bentzen, Jeanet S. 2020. In Crisis, We Pray: Religiosity and the COVID-19 Pandemic. CEPR Discussion Paper DP14824. May. Available online: https: / / ssrn.com/abstract=3615587 (accessed on 2 September 2021).

Boguszewski, Rafał, Makowska Marta, Bozewicz Marta, and Podkowinska Monika. 2020. The COVID-19 Pandemic's Impact on Religiosity in Poland. Religions 11: 646. [CrossRef]

Bryce Yaden, David. 2019. The Psychology of Religious Rituals and Practices. In Rituals and Practices in World Religions Cross-Cultural Scholarship to Inform Research and Clinical Contexts. Edited by David Bryce Yaden, Yukun Zhao, Kaiping Peng and Andrew B. Newberg. London: Springer, pp. 17-30.

Bunkachō [Japanese Agency for Cultural Affair]. 2020. Shūkyō nenkan [Religions Yearbook]. Tokyo: Gyōsei, Available online: https: //www.bunka.go.jp/tokei_hakusho_shuppan/hakusho_nenjihokokusho/shukyo_nenkan/pdf/r02nenkan.pdf (accessed on 1 July 2021). 
Büssing, Arndt. 2019. Measuring Spirituality and Religiosity in Health Research. In Spirituality, Religiousness and Health. Edited by Giancarlo Lucchetti, Prieto Peres, Damiano Mario Fernando and Rodolfo Furlan. London: Springer, pp. 11-31.

Cabinet Office of Japan. 2021a. Koronaka no josei heno eikyō to kadai ni kansuru kenkyūkai hōkokusho: Dare hitori torinokosanai posuto korona no shakai he [Study Group Report on Impacts and Challenges for Women during the Coronavirus Pandemic: Toward a Post-Pandemic Society That Leaves No One Behind]. Gender Equality Bureau. April 28. Available online: https: //www.gender.go.jp/kaigi/kento/covid-19/siryo/pdf/post_honbun.pdf (accessed on 1 July 2021).

Cabinet Office of Japan. 2021b. Reiwa 2 nendo DV sōdankensū no suii (Number of Consultations for Domestic Violence in the 2020 Fiscal Year). Gender Equality Bureau. Available online: https://www.gender.go.jp/policy/no_violence/pdf/soudan_kensu.pdf (accessed on 1 July 2021).

Cavaliere, Paola. 2015. Promising Practices: Women Volunteers in Japanese Religious Civil Society. Leiden: EJ Brill Publishers.

Cavaliere, Paola. 2018. Tenrikyō. In Encyclopaedia of Women and World Religions: Faith and Culture across History. Edited by Susan De Gaia. Santa Barbara: ABC-Clio, vol. 2, pp. 289-90. ISBN 978-1-4408-4849-0.

Cavaliere, Paola. 2019a. Women between Religion and Spirituality: Observing Religious Experience in Everyday Japanese Life. Religions 10: 377. [CrossRef]

Cavaliere, Paola. 2019b. Female leadership in contemporary Japanese religious organisations: The case of Shinnyoen. Osaka Human Sciences 5: 139-56. [CrossRef]

Cavaliere, Paola. 2021a. Religious Institutions in Japan Responding to Covid-19-Induced Risk and Uncertainty: Some Preliminary Considerations. Journal of Religion in Japan 10: 31-63. [CrossRef]

Cavaliere, Paola. 2021b. Articulating the neoliberal motherhood discourse: Visions of gender in Japanese new religions. In The Routledge Handbook of Religion, Gender and Society. Edited by Tomalin Emma and Starkey Caroline. London: Routledge, Part 2, Chapter 20.

Chung, Heejung. 2020. Return of the 1950s Housewife? How to Stop Coronavirus Lockdown Reinforcing Sexist Gender Roles. The Conversation. March 30. Available online: https:/ / theconversation.com/return-of-the-1950s-housewife-how-to-stop-coronaviruslockdown-reinforcing-sexist-gender-roles-134851 (accessed on 1 July 2021).

Colaizzi, Paul F. 1978. Psychological research as a phenomenologist views it. In Existential Phenomenological Alternatives for Psychology. Edited by Valle Ronald S. and King Mark. New York: Open University Press, pp. 48-71.

Dayan, Jacques, Christian Creveuil, Maureen N. Marks, Sue Conroy, Michel Herlicoviez, Michel Dreyfus, and Sylvie Tordjam. 2006. Prenatal depression, prenatal anxiety, and spontaneous preterm birth: A prospective cohort study among women with early and regular care. Psychosomatic Medicine 68: 938-46. [CrossRef]

de Rezende-Pinto, Alexandre, Silva Curcio Schumann Cristiane, and Moreira-Almeida Alexander. 2019. Spirituality, Religiousness and Mental Health: Scientific Evidence. In Spirituality, Religiousness and Health. Edited by Lucchetti Giancarlo, Prieto Peres, Mario Fernando Damiano and Rodolfo Furlan. London: Springer, pp. 69-86.

Del Castillo, Fides A., Hazel T. Biana, and Jeremiah J. B. Joaquin. 2020. ChurchInAction: The role of religious interventions in times of COVID-19. Journal of Public Health 42: 633-34. [CrossRef] [PubMed]

Edara, Inna R., Fides del Castillo, Gregory S. Ching, and Clarence D. del Castillo. 2021. Religiosity, Emotions, Resilience, and Wellness during the COVID-19 Pandemic: A Study of Taiwanese University Students. International Journal Environmental Research Public Health 18: 6381. [CrossRef]

Enarson, Elaine. 1998. Through Women's Eyes: A Gendered Research Agenda for Disaster Social Science. Disasters 22: 157-73. [CrossRef] [PubMed]

Enarson, Elaine, Alice Fothergill, and Lori Peek. 2007. Gender and Disaster: Foundations and Directions. In Handbook of Disaster Research. Handbooks of Sociology and Social Research. Edited by Havidán Rodríguez, Enrico L. Quarantelli and Russell R. Dynes. New York: Springer, pp. 130-46. [CrossRef]

Ferrell, Betty R., George Handzo, Tina Picchi, Christina Puchalski, and William E. Rosa. 2020. The urgency of spiritual care: COVID-19 and the critical need for whole-person palliation. Journal of Pain and Symptom Management 60: e7-e11. [CrossRef] [PubMed]

Gard, Tim, Jessica J. Noggle, Christal L. Park, David R. Vago, and Angela Wilson. 2014. Potential self-regulatory mechanisms of yoga for psychological health. Frontiers in Human Neuroscience 8: 770. [CrossRef] [PubMed]

Guendelman, Simon, Sebastian Medeiros, and Hagen Rampes. 2017. Mindfulness and emotion regulation: Insights from neurobiological, psychological, and clinical studies. Frontiers in Psychology 8: 220. [CrossRef]

Hart, Curtis W., and Harold G. Koenig. 2020. Religion and Health During the COVID-19 Pandemic. Journal of Religion and Health 59: 1141-43. [CrossRef] [PubMed]

Horie, Norichika. 2009. Spirituality and the spiritual in Japan: Translation and transformation. Journal of Alternative Spiritualities and New Age Studies 5: 1-15.

Horie, Norichika. 2021. Poppu supirichuariti: Mediaka sareta shūkyōsei (Pop Spirituality: Mediatised Religiosity). Tokyo: Iwanami Shoten.

Inaba, Keishin. 2018. Cooperation between Religious People and Social Actors during the Kumamoto Earthquake. Bulletin of the School of Human Sciences 44: 249-62. Available online: https://ir.library.osaka-u.ac.jp/repo/ouka/all/68300/hs44_249.pdf (accessed on 1 July 2021). 
Isomura, Kentarō. 2007. 'Supirichuaru' wa naze ryūkō suru (Why Is 'Spiritual' Popular?). Tokyo: PHP Institute.

Ivtzan, Itai, and Angeliki Papantoniou. 2014. Yoga meets positive psychology: Examining the integration of hedonic (gratitude) and eudaimonic (meaning) well-being in relation to the extent of yoga practice. Journal of Bodywork and Movement Therapies 18: 183-89. [CrossRef] [PubMed]

Kato, Akiko, and Rajib Shaw. 2020. Yoga and stress management during and post COVID-19 urban lifestyle in Japan. Asian Journal of Complementary and Alternative Medicine 8: 48-54.

Khoury, Jennifer E., Leslie Atkinson, Teresa Bennett, Susan M. Jack, and Andrea Gonzalez. 2021. COVID-19 and mental health during pregnancy: The importance of cognitive appraisal and social support. Journal of Affective Disorders 282: 1161-69. [CrossRef] [PubMed]

King, Ursula. 2009. The Search for Spirituality: Our Global Quest for Meaning and Fulfillment. Norwich: Canterbury Press.

Kittay, Eva Feder. 1999. Love's Labour: Essays on Women, Equality and Dependency. New York: Routledge.

Koenig, Harold G. 2008. Medicine, Religion, and Health: Where Science and Spirituality Meet. West Conshohocken: Templeton Foundation Press.

Koenig, Harold G., Kenneth I. Pargament, and Julien Nielsen. 1998. Religious coping and health status in medically ill hospitalised older adults. The Journal of Nervous and Mental Disease 186: 513-21. [CrossRef] [PubMed]

Komatsu, Kayoko. 2017. Spirituality and Women in Japan. Japanese Journal of Religious Studies 44: 123-38. [CrossRef]

Kubo, Takahiro, Daichi Sugawara, and Akihiro Masuyama. 2021. The effect of ego-resiliency and COVID-19-related stress on mental health among the Japanese population. Personality and Individual Differences 175: 110702. [CrossRef] [PubMed]

Lima, Carlos K. T., Poliana M. de Medeiros Carvalho, Igor de A. S. Lima, Jose V. A. de Oliveira Nunes, Jeferson S. Saraiva, Ricardo I. de Souza, Claudio G. L. da Silva, and Modesto L. R. Neto. 2020. The emotional impact of Coronavirus 2019-nCoV (new Coronavirus disease). Psychiatry Research 287: 112915. [CrossRef]

Lucchetti, Giancarlo, Peres Prieto, Fernando Mario, and Rodolfo Furlan Damiano, eds. 2019. Spirituality, Religiousness and Health London: Springer.

Lucchetti, Giancarlo, Leonardo Garcia Góes, Stefani Garbulio Amaral, Gabriela Terzian Ganadjian, Isabelle Andrade, Paulo Othávio de Araújo Almeida, Victor Mendes do Carmo, and Maria Elisa Gonzalez Manso. 2020. Spirituality, religiosity and the mental health consequences of social isolation during Covid-19 pandemic. International Journal of Social Psychiatry, 1-8. [CrossRef]

McGuire, Meredith B. 2008. Lived Religion: Faith and Practice in Everyday Life. Oxford: Oxford University Press.

McLaughlin, Levi. 2013. What Have Religious Groups Done After 3.11? Part 2: From Religious Mobilization to 'Spiritual Care'. Religion Compass 7: 309-25. [CrossRef]

Moreira da Silva, Jeorge. 2019. Why You Should Care About Unpaid Care Work. OECD Development Matters. March 18. Available online: https:/ / oecd-development-matters.org/2019/03/18/why-you-should-care-about-unpaid-care-work (accessed on 1 July 2021).

MUFJ. 2021. Yangu kearā jittai ni can suru chōsa kenkyū (Survey on Young Carers). Sponsored by the Ministry of Health, Labour and Welfare. Available online: https:/ /www.murc.jp/wp-content/uploads/2021/04/koukai_210412_7.pdf (accessed on 1 July 2021).

Nagasu, Miwako, Kaori Muto, and Isamu Yamamoto. 2021. Impacts of anxiety and socio-economic factors on mental health in the early phases of the COVID-19 pandemic in the general population in Japan: A web-based survey. PLoS ONE 16: e0247705. [CrossRef]

Newberg, Andrew B. 2019. Neuroscientific Approaches Toward Understanding Rituals. In Rituals and Practices in World Religions Cross-Cultural Scholarship to Inform Research and Clinical Contexts. Edited by David Bryce Yaden, Kaiping Peng, Yukun Zhao and Andrew B. Newberg. London: Springer, pp. 31-46.

Nishihara, Mika, Yasuhide Nakamura, Toru Fuchimukai, and Mayumi Ohnishi. 2018. Factors associated with social support in child-rearing among mothers in post-disaster communities. Environmental Health and Preventive Medicine 23. [CrossRef] [PubMed]

Nita, Maria. 2019. 'Spirituality' in Health Studies: Competing Spiritualities and the Elevated Status of Mindfulness. Journal of Religion and Health 58: 1605-18. [CrossRef]

Nomura, Shuhei, Takayuki Kawashima, Daisuke Yoneoka, Yuta Tanoue, Eguchi Akifumi, Stewart Gilmour, Yumi Kawamura, Nahoko Harada, and Masahiro Hashizume. 2021. Trends in suicide in Japan by gender during the COVID-19 pandemic, up to September 2020. Psychiatric Research 295: 113622. [CrossRef]

Ochiai, Emiko. 2013. Kindai sekai no tenkan to kazoku hendō no riron-Ajia to yōroppa. (The logic of global family change in transforming modernity: Focusing on Asia and Europe). Shakaigaku Hyōka 256: 533-52. [CrossRef]

Pew Forum. 2021. More Americans Than People in Other Advanced Economies Say COVID-19 Has Strengthened Religious Faith. Available online: https:/ / www.pewforum.org/2021/01/27/more-americans-than-people-in-other-advanced-economies-saycovid-19-has-strengthened-religious-faith/ (accessed on 1 July 2021).

Pirutinsky, Steven, Aaron D. Cherniak, and David H. Rosmarin. 2020. COVID19, mental health, and religious coping among American Orthodox Jews. Journal of Religion and Health 59: 2288-301. [CrossRef] [PubMed]

Power, Kate. 2020. The COVID-19 pandemic has increased the care burden of women and families. Sustainability: Science, Practice and Policy 16: 67-73. [CrossRef]

Prazeres, Felipe, Ligia Passos, Jose Augusto Simões, Pedro Simões, Carlos Martins, and Andreia Teixeira. 2021. COVID-19-Related Fear and Anxiety: Spiritual-Religious Coping in Healthcare Workers in Portugal. International Journal of Environmental Research and Public Health 18: 220. [CrossRef] [PubMed] 
Rajkumar, Ravi P. 2020. COVID-19 and mental health: A review of the existing literature. Asian Jouranl of Psychiatry $52: 102066$. [CrossRef] [PubMed]

Reader, Ian. 1991. Religion in Contemporary Japan. Honolulu: University of Hawaii Press.

Reader, Ian, and George Tanabe. 1998. Practically Religious: Worldly Benefits and the Common Religion of Japan. Honolulu: University of Hawai'i Press.

Rubertsson, Christine, Hellström Jonas, Cross Maddalena, and Sydsjö Gunilla. 2014. Anxiety in early pregnancy: Prevalence and contributing factors. Archives of Women's Mental Health 17: 221-28. [CrossRef]

Sado, Mitsuhiro. 2021. Maindofurunesu de koronaka demo kokoro shinayaka (Mindfulness during COVID-19 for a resilient mind). Anzensei no Hiroba 62: 8-17.

Sahni, Pooja S., Kamlesh Singh, Nitesh Sharma, and Rahul Garg. 2021. Yoga an effective strategy for self-management of stress-related problems and well-being during COVID19 lockdown: A cross-sectional study. PLoS ONE 16: e0245214. [CrossRef] [PubMed]

Saito, Shota, Huyen Thi Thanh Tran, Ruan Qi, Kenji Suzuki, Toru Takiguchi, Kazuo Ishigami, Shinichi Noto, Sachiko Ohde, and Osamu Takahashi. 2021. Psychological impact of the state of emergency over COVID-19 for nonpermanent workers: A Nationwide followup study in Japan. BMC Public Health 21: 334. [CrossRef]

Shechter, Ari, Franchesca Diaz, Nathalie Moise, D. Edmund Anstey, Siqin Ye, Sachin Agarwal, Jerey L. Birk, Daniel Brodie, Diane E. Cannone, Bernard Chang, and et al. 2020. Psychological distress, coping behaviors, and preferences for support among New York healthcare workers during the COVID-19 pandemic. General Hospital Psychiatry 66: 1-8. [CrossRef] [PubMed]

Shigemura, Jun, Robert J. Ursano, Joshua C. Morganstein, Mie Kurosawa, and David M. Benedek. 2020. Public responses to the novel 2019 coronavirus (2019-nCoV) in Japan: Mental health consequences and target populations. Psychiatry and Clinical Neurosciences 74: 277-83. Available online: https:/ / onlinelibrary.wiley.com/doi/epdf/10.1111/pcn.12988 (accessed on 1 July 2021). [CrossRef] [PubMed]

Shimazono, Susumu. 2011. Secularisation in Japan and New Spirituality. Sociology of Religion and the Perspective of Comparative Culture and Civilisation. Hosei University Repository 57: 23-34.

Sugawara, Daichi, Akihiro Masuyama, Takahiro Kubo, Yuan Gu, Tee Yu Jin, Raja I. Shah, Evone Y. Phoo, Siew Li Ng, and Yuta Chishima. 2020. RE-COVER: REsilience for COVID-19 in Each Region. PSJ Data, Data set, OSF. Available online: https: / / doi.org/10.17605/OSF.IO/P56GA (accessed on 2 September 2021).

Sugaya, Nagisa, Tetsuya Yamamoto, Naho Suzuki, and Chigusa Uchiumi. 2021. Social isolation and its psychosocial factors in mild lockdown for the COVID-19 pandemic: A cross-sectional survey of the Japanese population. BMJ Open 11: e048380. [CrossRef]

Taniyama, Yozo. 2017. Iryōsha to shūkyōsha no tameno supirichuaru kea: Rinshō shükyoshi no shiten kara (Spiritual Care for Medical Staff and Religious Professionals: From the Perspective of the Certified Spiritual Care Worker). Tokyo: Chugai Igakusha.

Taylor, Charles. 1991. Sources of the Self: The Making of the Modern Identity. Cambridge: Cambridge University Press.

Thibaut, Florence, and Patricia J. M. van Wijngaarden-Cremers. 2021. Women's Mental Health in the Time of Covid-19 Pandemic. Frontiers in Global Women's Health. [CrossRef]

Ueda, Michiko, Robert Nordström, and Tetsuya Matsubayashi. 2020. Suicide and Mental Health during the COVID-19 Pandemic in Japan. Available online: https:/ / doi.org/10.1101/2020.10.06.20207530 (accessed on 2 September 2021).

World Economic Forum. 2020. Global Gender Gap Report. Available online: http:/ / www3.weforum.org/docs/WEF_GGGR_2020.pdf (accessed on 1 July 2021).

World Health Organization (WHO). 2021. Coronavirus Disease 2019 (Covid-19) Situation Report-Weekly Epidemiological Update on COVID-19-25 May 2021. Available online: https:/ /www.who.int/publications/m/item/weekly-epidemiological-update-oncovid-19---25-may-2021 (accessed on 1 July 2021).

Woodhead, Linda. 2008. Gendering Secularisation Theory. Social Compass 55: 189-95. [CrossRef]

Xiong, Jiaqi, Orly Lipsitz, Flora Nasri, Leanna M. W. Lui, Hartej Gill, Lee Phan, David Chen-Li, Michelle Iacobucci, Roger Ho, Amna Majeed, and et al. 2020. Impact of COVID-19 pandemic on mental health in the general population: A systematic review. Journal of Affective Disorders 277: 55-64. [CrossRef]

Yamamoto, Tetsuya, Chigusa Uchiumi, Nao Suzuki, Junichiro Yoshimoto, and Eric Murillo-Rodriguez. 2020. The Psychological Impact of 'Mild Lockdown' in Japan during the COVID-19 Pandemic: A Nationwide Survey under a Declared State of Emergency. International Journal Environmental Research Public Health 17: 9382. [CrossRef] [PubMed]

Yamamura, Eiji, and Yoshiro Tsustsui. 2021. School closures and mental health during the COVID-19 pandemic in Japan. Journal of Population Economics 34: 1261-98. [CrossRef] [PubMed]

Yamane, Sumika. 2013. Genpatsu jiko ni yoru 'boshi hinan' mondai to sono shien: Yamagataken ni okeru hinansha chōsa no dēta kara ("Mother and child" evacuation problem caused by the nuclear accident and its support: Data from the evacuees survey in Yamagata Prefecture). Yamagata University Humanities Department Bulletin 10: 37-51.

Yıldırım, Murat, and Gökmen Arslan. 2020. A Moderated Mediation Effect of Stress-Related Growth and Meaning in Life in the Association Between Coronavirus Suffering and Satisfaction with Life: Development of the Stress-Related Growth Measure. Frontiers in Psychology 12: 529. [CrossRef] 